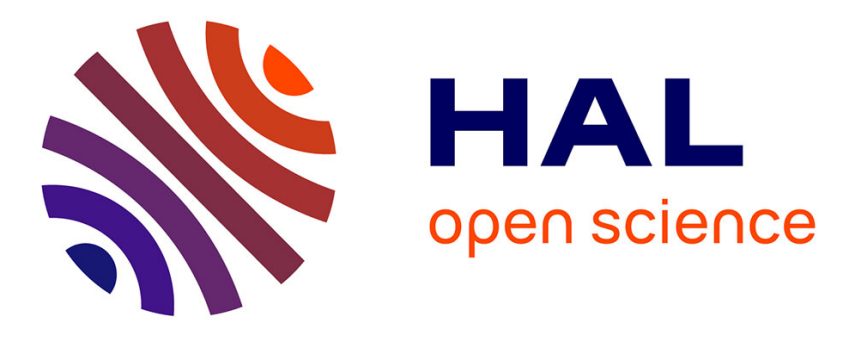

\title{
On-site identification of early Böttger red stoneware using portable XRF/Raman instruments: 2, glaze \& gilding analysis
}

Gulsu Simsek, Philippe Colomban, Francesca Casadio, Ludovic Bellot-Gurlet, Ghenete Zelleke, Katherine T. Faber, Véronique Milande, Laurence Tilliard

\section{To cite this version:}

Gulsu Simsek, Philippe Colomban, Francesca Casadio, Ludovic Bellot-Gurlet, Ghenete Zelleke, et al.. On-site identification of early Böttger red stoneware using portable XRF/Raman instruments: 2, glaze \& gilding analysis. Journal of the American Ceramic Society, 2015, 98 (10), pp.3006-3013. 10.1111/jace.13720 . hal-01172632

\section{HAL Id: hal-01172632 https://hal.sorbonne-universite.fr/hal-01172632}

Submitted on 7 Jul 2015

HAL is a multi-disciplinary open access archive for the deposit and dissemination of scientific research documents, whether they are published or not. The documents may come from teaching and research institutions in France or abroad, or from public or private research centers.
L'archive ouverte pluridisciplinaire HAL, est destinée au dépôt et à la diffusion de documents scientifiques de niveau recherche, publiés ou non, émanant des établissements d'enseignement et de recherche français ou étrangers, des laboratoires publics ou privés. 


\section{On-site identification of early Böttger red stoneware using portable XRF/Raman instruments: 2, glaze \& gilding analysis}

Running title: Glaze \& gilding analysis of early Böttger red stoneware

G. Simsek ${ }^{1,2,3}$, Ph. Colomban ${ }^{4 *}$, F. Casadio ${ }^{3}$, L. Bellot-Gurlet ${ }^{4}$, G. Zelleke ${ }^{3}$, K.T. Faber ${ }^{1}$, V. Milande ${ }^{5}$, and L. Tilliard ${ }^{5}$

${ }^{1}$ Department of Materials Science and Engineering, Northwestern University, Evanston, IL, USA

${ }^{2}$ Labex MiChem, Ladir, UPMC, 4 Place Jussieu, c49, 75252 Paris Cedex 05, France

${ }^{3}$ Art Institute of Chicago, Chicago, IL, USA

${ }^{4}$ Sorbonne Universités, MONARIS, umr 8233 CNRS, UPMC Univ. Paris 06, 4 Place Jussieu, c49, 75252

Paris Cedex 05, France

${ }^{5}$ Cité de la Céramique - Sèvres \& Limoges, Place de la Manufacture, 92310 Sèvres, France

* corresponding author: Ph. Colomban philippe.colomban@upmc.fr

\section{Abstract}

Twenty-one glazed red stoneware objects, with gilded or gold-painted decor from different collections (Cité de la Céramique, Sèvres, France; Art Institute of Chicago, USA; a private collection) attributed to $18^{\text {th }}$ century Böttger, Meissen (Saxony) have been analyzed with a portable X-ray fluorescence spectrometer (XRF) and portable or fixed Raman microspectrometer in laboratory/museum/collector rooms. Analysis was aimed at gaining a deeper understanding of the technology of production of the gilding and black glaze, to augment what is known from the limited literature. Three different techniques to obtain a golden décor emerged as a result of this study: i) a true gilding with gold, ii) gold with mercury, and iii) an alloy of copper and zinc. 


\section{Introduction}

The black-glazed red stoneware (sometimes called Boccaro ware) developed by Ehrenfried Walther von Tschirnhaus and Johann Friedrich Böttger at the Court of Augustus the Strong, Prince-Elector of Saxony was celebrated as a "completely new kind of porcelain”1 by their contemporaries and represents the first step in porcelain production in Saxony.

Notwithstanding the historical importance of this highly technological and artistic

achievement, in-depth technical studies of Böttger stoneware and its decoration are limited. ${ }^{2-18}$ Böttger started the manufacture of red stoneware composed of iron-rich clays firstly in 1706 in Meissen and two years later in Dresden. Production continued serially until the introduction of white porcelain in 1714 and took place occasionally after $1717 .{ }^{2,6}$ Böttger stoneware was produced with two main types of surface finishes; unglazed and glazed wares. An intaglio carving technique was also used to further enhance the decoration, exploiting the interplay between the polished and unpolished, glazed and unglazed areas creating a harmonious work of contrasting texture and visual properties. ${ }^{1}$

The brown- or black-glazed stoneware was often decorated with gold and might have included depictions of East Asian or western motifs painted with unfired (cold) colors. Böttger was one of the earliest recorded pioneers of gold decoration, which might be a result of the fact that he was a young alchemist before his attempts to produce porcelain. According to Bishop and Sutton ${ }^{12}$, he experimented both with the Chinese/Vietnamese ancient technology of using gold leaf physically bound to the ceramic surface ${ }^{19,20}$ and also with the $18^{\text {th }}$ century technique of application of liquid gold (i.e. finely divided gold powder applied in a medium, and successively fired). ${ }^{20}$ They report that he started by adhering the gold leaf first and heating the artifact over hot coals to make it more durable. Later, in order to prevent stripping and lumping problems caused by gilding, he tried to prepare a mixture of gold 
powder with ferrous sulfate in aqua regia to produce "a quite beautiful and very fine precipitate”, according to the new technique introduced by Kunkel. ${ }^{12,21}$ After the death of Böttger, the new director of the Meissen Factory, Johannes Gregorius Höroldt ${ }^{22}$ continued to $^{2}$ develop the gilding technique of his predecessor with the aim of achieving a reliable, durable gold layer and he also set about producing a range of fired colors for the painted decorations, some of whose recipes have been used up to this day.

Importantly, when analyzing the material composition of the applied decoration one should always keep in mind the possibility of later embellishment, long after the object's production, as has been also documented for white hard paste porcelain at Meissen. ${ }^{14}$

Most of the previous studies on Böttger stoneware are primarily focused on the measurements of the composition of the red stoneware paste in order to determine its main characteristics and trying to distinguish it from other stoneware of different origins such as those produced in Europe in the $17^{\text {th }}$ and $18^{\text {th }}$ centuries at Delft (Holland), Staffordshire (England), Plaue on Havel and Bayreuth (Germany) and various production centers in China. ${ }^{17}$

The present study focuses on the investigation of the decoration of 21 objects from different collections (Département du Patrimoine et des Collections de la Cité de la Céramique, Sèvres, France, here after noted SB; Art Institute of Chicago, USA (A); private collection (PC)) ornate with dark glazes varying in color from chocolate brown to deep black, with gilding and a limited amount of cold-color decoration (Fig. 1). The 16 artifacts from Sèvres represent a key benchmark group of securely attributed objects. This is an ideal group to derive objectsbased inferences on Böttger's $18^{\text {th }}$ century workshop practices due to their excellent provenance as gifts from Meissen to Sèvres (1837 and 1875), as well as purchases made in Dresden by the director of the Sèvres porcelain manufactory Alexandre Brongniart (1836). The high value and significance of the objects studied, all of museum quality, prevented any sampling for the study, thus directing the research to an exclusively non-invasive analytical 
approach. The sample set chosen for this investigation makes this one of the largest published studies focusing on the decoration of the red stoneware, ${ }^{9,13-16,18}$ as most of the few existing publications focus on the body composition ${ }^{4,6,7,11}$. In most of these previous works the darkly glazed examples were only barely studied. The aim of this paper is thus to contribute to a better knowledge of the first Meissen production and to advance our understanding of the different methods used to produce dark glazes and gold decoration.

\section{Experimental Set-up}

\subsection{X-ray fluorescence spectroscopy (XRF)}

XRF analysis was performed using a Brüker Tracer III-V (Brüker AXS, Karlsruhe, Germany) portable system equipped with a rhodium (Rh) target X-ray tube that was operated at $33 \mathrm{kV}$, $2 \mu \mathrm{A}$ to identify the network modifiers and coloring/gilding agents found on the glaze as previously described. ${ }^{17} \mathrm{~A}$ vacuum pump was used during testing to enhance the detection of low $\mathrm{Z}$ elements (from aluminum to titanium). The beam size at the surface is roughly 0.15 $\mathrm{cm}^{2}$. Due to the heterogeneity in composition and variation of the glaze thickness, the measurements were carried out on at least three different areas of the enamel. The results are reported as the mean values of all the individual point analyses done on each object. For qualitative evaluation purposes the $\mathrm{K} \alpha$ lines of $\mathrm{Al}, \mathrm{Si}, \mathrm{K}, \mathrm{Ca}$, the transition metal elements (Ti, Cr, Mn, Fe, Cu, Zn) and trace elements (Rb, Sr, Y, Zr) as well as the $\mathrm{L}$ spectral lines of lead were taken into consideration. The L spectral lines of gold and mercury were also considered in cases of glaze ornamentation and gilding. As silicon is the major element of both glaze and body, Si counts are measured between 10.000 (min.) and.40.000 (max). In order to compare measurements where the instrument tip-surface artifact distance varies, most of the element mean area counts are normalized by those of Si. Complementary XRF analysis of gold decors was also performed using a NITON XL3t GOLDD+ (Thermofisher, 
Tewksbury, USA) portable system equipped with a silver anode X-ray tube and an SDDGOLDD detector that was operated at $50 \mathrm{kV} 200 \mu \mathrm{A}$ in order to corroborate and strengthen the previous results. The beam size of the instrument was $\sim 0.5 \mathrm{~cm}^{2}$ and a camera visualized the analyzed spot. Typically gold leaf thickness larger than $0.2 \mu \mathrm{m}$ are sufficient to avoid contribution of the gold substrate.

\subsection{Raman spectroscopy (RS)}

Raman analyses were performed in-situ using a laboratory system for analyzing the coffee pot of the Art Institute of Chicago and a portable unit for the private and Sèvres Museum’s collections. A confocal Labram 300 Horiba-Jobin Yvon Raman spectrometer (Lille, France) with a $532 \mathrm{~nm}$ green laser was used at the Art Institute (Fig. S1, Supplementary Materials). Raman measurements were carried out with a 50x long working distance (LWD) objective (NA $=0.55$, Olympus) to avoid any contact with the surface of the object. The recording time of a spectrum varied between 30 and 120 seconds. Because the stoneware paste is rich in iron oxide, a low laser power was used on the objects in order to prevent any phase transformation of iron oxide (e.g. from magnetite to hematite). Most of the analyses were performed interposing neutral density filters between the incoming excitation and the 50x LWD objective, the laser power being equal or less than $1 \mathrm{~mW}$ at the sample surface. The mobile analyses were performed using a portable HE532 (Horiba Jobin Yvon, Lille, France), equipped with a Peltier-cooled (200K) matrix charge coupled device (CCD) detector associated with a Laser Quantum Ventus (Stockport, UK) YAG laser, which has a nominal maximum power of $80 \mathrm{~mW}$. The spectrum collecting time was less than 10 seconds with a resolution of $\sim 4 \mathrm{~cm}^{-1}$. A 50x LWD objective (NA=0.45, Nikon) was used during measurements. The illumination power was controlled with the laser power control and a variable size hole at the entrance of the remote optical head fiber connected to the laser and 
the spectrometer (SuperHead ${ }^{\mathrm{TM}}$, Horiba Jobin Yvon, Lille, France) so as to further reduce the laser power to about 5-8 $\mathrm{mW}$ at the sample with $532 \mathrm{~nm}$ laser excitation. Baseline subtraction was performed during post-processing of the spectra to assist with the interpretation and to derive the polymerization index for the glassy phases as extensively explained in the literature. ${ }^{23-27}$

\subsection{Colorimetry}

Color measurements were performed on the glazes by an X-Rite GRETAG MACBETH SpectroEye portable spectrophotometer equipped with a gas-filled tungsten light source. The internal spectral resolution is $3.3 \mathrm{~nm}$ and the reflectance spectrum is between 380 and $730 \mathrm{~nm}$. Color coordinates were expressed in the CIE (Commission International pour l'éclairage) $\mathrm{L}^{*} \mathrm{a} * \mathrm{~b} *$ color system, using the illuminant $\mathrm{C}$ and the $2^{\circ}$ viewing angle.

\section{Objects}

This paper concerns the characterization of 21 glazed Böttger stoneware objects examined at the Cité de la Céramique of Sèvres, the Art Institute of Chicago and an important private collection (See Fig. 1). Specifically one object was analyzed at the Art Institute, 16 objects at Sèvres, and four objects in a private collection. Detailed information about the analyzed objects that are part of publicly held collections is provided as supplementary material (See Table S1). This study also includes a brief overview of the results of Raman measurements on the body of mostly unglazed stoneware, whose characterization with XRF is extensively discussed in a previous paper ${ }^{17}$. The glazes of the objects examined vary in color from black to dark brown through gradations of reddish and chocolate brown, and for the most part also include golden decorations (Fig. 1). 


\section{Results and Discussion}

\section{(1) Body}

Collecting useful XRF data in the often very thin and sometimes faceted unglazed rims and bases of glazed objects is difficult, given the relatively large aperture of the XRF instrument used. In fact, the unglazed rim often only partially covers the aperture of the XRF instruments, a factor that can significantly affect count rates. When this is compounded by geometry and orientation effects it can significantly affect the relative count fractions for important elements such as $\mathrm{Al}$ and $\mathrm{Ti}$, as demonstrated by Bezur and Casadio ${ }^{15}$. Often such exposed thin rims are also smeared with residual Pb-rich glaze material, which further affects the reliability of relative count rates. Therefore, reliable XRF measurements of the body composition were obtained only for three of the studied glazed objects, which had large flat unglazed bases (SB 2244-12, coffee pot; SB 2244-14, cup; SB 2272-10, bottle). Analysis revealed a composition of major elements $(\mathrm{Si}, \mathrm{Al}, \mathrm{Ti}, \mathrm{Fe})$ and trace elements $(\mathrm{Zr}, \mathrm{Rb}, \mathrm{Sr}, \mathrm{Ni}$, $\mathrm{Cu}, \mathrm{Zn}, \mathrm{Cr}$ ) representative of the raw materials used, as well as fluxes ( $\mathrm{K}, \mathrm{Ca}$ and $\mathrm{Pb}$ ) representative of the production technology. These agreed well with the fairly large compositional range measured for Böttger stoneware production, as previously discussed (Fig. S2). ${ }^{17}$ Representative as-recorded Raman spectra for unglazed Böttger red stoneware previously studied with $\mathrm{XRF}^{17}$ are presented in Fig 2, the most frequent spectra correspond to hematite, rutile, and anatase. Actually, two different hematite signatures are observed, that of pure hematite $(\mathrm{H})$ and broader signature typical of hematite solid solution $\left(\mathrm{H}^{*}, \mathrm{Al}\right.$ or $\mathrm{Ti}$ replacing some Fe atoms). These compounds were already identified in previous works on Meissen porcelain and stoneware. ${ }^{8,9}$ These phases have very high Raman scattering crosssection and are therefore more easily detected. While hematite is definitely a predominant phase, the same cannot be said of Ti-rich inclusions. The carbon $1350-1600 \mathrm{~cm}^{-1}$ doublet is commonly observed, indicating a final firing under strong reducing atmosphere. The signature 
of quartz at $465 \mathrm{~cm}^{-1}$ is also detected, as well as the $\sim 510 \mathrm{~cm}^{-1}$ peak indicating unreacted feldspar grains, as commonly observed for porcelain and stoneware. ${ }^{8,9,19,28,}$ The number of phases identified in-situ depends on the analyzed spot and in order to obtain a truly representative description of the phase distribution extensive Raman area mapping should be performed on samples removed and prepared as cross-sections, which were not available for this study.

\section{(2) The black and brown glazes}

Glazed Böttger stoneware is divided in groups in this study according to two broad classes of colors for their glazes: black or brown. Some of the objects are decorated with gilding or painting (Table 1 and Supplementary Materials, Table S1): six objects out of 21 have a brown glaze (Fig. 1). The color measurements of the glazes presented in the Table 1 show the differentiation between black and brown colors in terms of the higher level of $a^{*}$ (red) and $b^{*}$ (yellow) factors. As-recorded and baseline-subtracted Raman spectra are presented in Figs S3 and 3 a \& b, respectively. The $\mathrm{SiO}_{4}$ tetrahedron has a characteristic vibrational spectrum signature, which is slightly modified as a function of the geometric arrangement of each $\mathrm{SiO}_{4}$ tetrahedron vs. its neighbors and because of the electric perturbations due to neighboring cations. Because strong covalently bonded structures have Raman spectroscopic signatures orders of magnitude larger than those of ionic ones, the Raman spectrum of a silicate consists, as a first approximation, solely of the signature of the Si-O network. The Raman spectrum of silicate glass consists of two broad bands, one around $500 \mathrm{~cm}^{-1}\left(\mathrm{SiO}_{4}\right.$ bending vibrations) and one around $1000 \mathrm{~cm}^{-1}$ ( $\mathrm{SiO}_{4}$ stretching vibrations); librational/collective modes, i.e. the socalled Boson peak are observed below $300 \mathrm{~cm}^{-1} \cdot{ }^{23}$ Thus the Raman spectroscopic signature of amorphous (and crystalline) silicates, i.e. their peak wavenumbers and relative intensities, depend on the silicate nanostructure, in particular on the different tetrahedron types (isolated 
or sharing 1, 2, 3 or 4 oxygen atoms), and can be directly correlated to the glass degree of polymerization, null for isolated tetrahedral, maximal for tetrahedra sharing all their oxygen atoms with neighboring ones. Previous studies on glass, glaze and enamel ${ }^{9,23,24-27}$ developed a useful method for the classification of glass spectra that is based on the plot of Si-O bending peak area vs. that of the Si-O stretching peak area, the so-called polymerization index, Ip. All the Meissen’ glaze spectra show a strong Si-O stretching band peaking at $\sim 950 \mathrm{~cm}^{-1}$, characteristic of a lead-based glaze (Fig. 3a). ${ }^{21,25,29}$. The specific position of the Si-O bending convolution of bands (in the range of about 400 to $600 \mathrm{~cm}^{-1}$ ) depends on the O-Si-O angle, and hence, on the glass nanostructure, i.e. on the composition and processing. ${ }^{23-25}$ The boson peak (30-300 $\left.\mathrm{cm}^{-1}\right)$ is generally very strong, but has been suppressed by the baseline subtraction procedure. ${ }^{23-25}$ This procedure is necessary to enable the comparison of spectra recorded with fixed and portable instruments, i.e. with different baseline backgrounds. ${ }^{24,30}$ The strongest band of hematite, centered at $1330 \mathrm{~cm}^{-1}$ (resonance combination band) ${ }^{31}$, is detected in some glazes as is the carbon doublet. On the glaze decoration the carbon identified may actually be due to dust and/or the transformation of traces of organic materials on the surface into carbon black under the laser beam, especially when metal particles (gilding) are present in the illuminated spot. The metallic phases are very efficient conductors of the focused thermal energy of the laser, promoting transformation of residual organic matter into carbon.

It has been pointed out that the ratio of the area of the Si-O bending band vs. that of the stretching band is directly related to the degree of polymerization of the $\mathrm{SiO}_{4}$ network of the glass $^{23-27}$ (called the index of polymerization, Ip), and hence, to the fluxes used and the processing temperature of the glaze. Low Ip values (0.5-1.5) are measured for highly depolymerized glass such as lead-rich glazes; high Ip values (2.5-5) are measured for hard paste porcelain glazes, fired at high temperature with the body. ${ }^{23,26}$ Comparing the Ip values 
of the objects analyzed (Fig 3) two groups are visible, one with Ip $<2$, the other with Ip comprised between 2.5 and $\sim 4$. The first group is consistent with Petit Feu glazing. In this technique the PbO-rich glaze is applied on an already fired object, which is subsequently fired at temperature $<900-1000^{\circ} \mathrm{C} .^{25-27}$ The glazes with higher Ip values have likely been sintered at higher temperature. Additionally, it is interesting to note that the brown-glazed objects have lower Ip values than the black ones, which can be correlated to the chemical composition of the glaze. Attempts at comparing the Ip values calculated from the Raman spectra with the Sinormalized net area counts for Pb as measured by XRF (Fig. S4 Supplementary Materials) proved unsatisfactory. The Pb signals measured with XRF are significantly affected by the glaze thickness and contributions from the body due to the fact that the X-ray interaction volume is much larger than a single layer of glaze. Raman spectroscopy is thus better adapted to the glaze study as it is strictly a surface technique.

It is noteworthy to consider the XRF scatterplot of the normalized Pb vs. Ca net area counts (Fig. 4a). As described in a previous work ${ }^{17}$ the area counts for those elements have been normalized by those of silicon, in order to minimize the error due to the variable distance between the artifact and the XRF instrument tip. All of the brown glazes with the exception of SB 8405 tend to be clustered at net area counts for $\mathrm{Pb}$ and $\mathrm{Ca}$ fluxing agents. Figure 4b, revealing the index of polymerization vs. the position of the Si-O bending vibration shows two clearly divided groups that are largely correlated with glaze color. Moreover, from the scatterplot showing the normalized $\mathrm{Cu}$ vs. Ni and Mn XRF net area counts in Fig. 5, similar differentiation is seen. The group with higher Si-O bending wavenumber fit with the group with higher $\mathrm{Cu}$ and $\mathrm{Mn}$ normalized net area counts. This may indicate the use of different firing conditions. By observing these graphs it appears that the black and brown glazes are reasonably well differentiated, with the black glaze showing relatively higher normalized net 
area counts for $\mathrm{Mn}$ and $\mathrm{Cu}$, leading to the conclusion that the black colour is obtained by addition of manganese and copper (Fig. 5b).

\section{(3) Colored Décor and Gilding}

Four objects exhibit a colored décor executed with cold (unfired) colors over the black glaze: a coffee pot (A1995-96), a tankard (SB2244-7), a sake bottle (SB2244-8) and a bottle (SB2272-10). Since the colored decoration was not the primary focus of this study it was not analyzed systematically. Only a few areas of green, rose, white and blue colors were analyzed with the portable Raman instrument, but not all areas tested rendered useful spectra. ${ }^{8}$ A weak increase of the laser power led to the appearance of the carbon doublet, visible also in some of the spectra presented in Fig. 3b and assigned to the thermal degradation of the organic medium of the cold color decoration. This confirms that colored décor is a cold painting and not due to a coloring agent dispersed in a glaze and successively fired.

Fig. 3b shows representative spectra recorded on the coloured/gilded decorations. The spectrum recorded on the white decor of the sake bottle SB2244-8 shows a strong peak at $\sim 815 \mathrm{~cm}^{-1}$, characteristic of arsenate white. ${ }^{21,32}$ Due to the time limitations of access to the item, XRF analysis of this décor was not carried out. Additionally, the peak at $980 \mathrm{~cm}^{-1}$ can be assigned to calcium phosphate, a white pigment also documented in the glaze decoration of Medici porcelain. ${ }^{21,29,33}$ Arsenate white was first used in Venice at the end of $16^{\text {th }}$ century to produce lattimo glass objects but it was not used as porcelain enamel pigment before the $19^{\text {th }}$ century. ${ }^{21}$ Therefore this finding brings into question whether Böttger's workshop demonstrated an innovative use of the material or if a later $\left(19^{\text {th }}\right.$ c. $)$ decoration was applied to an otherwise black glazed $18^{\text {th }}$ century piece. Although this practice was not unusual at the time $^{14}$, both by dealers or at the factory, given the provenance of this object, it is unlikely that a Meissen or a Dresden dealer would have restored the white areas before Brongniart gave 
the sake bottle to Sevres in 1836. A 2009 study by Miliani et al. ${ }^{18}$ conducted on 21 objects in the Dresden collection (Staatliche Kunstsamlungen) demonstrated the use of the following pigments: lead white (cerussite and hydrocerussite), vermilion, copper greens, azurite, and Prussian blue. However the present study also shows a mixture of gypsum $\left(1010 \mathrm{~cm}^{-1}\right)$, chalk (1080 $\left.\mathrm{cm}^{-1}\right)$ and hematite for the cup SB224- 9, so clearly more studies on even higher numbers of glazed artefacts are required to establish the full range of Böttger's cold color palette for stoneware and confirm or disprove his innovative use of arsenate white. Certainly the finding of very early uses of Prussian blue, as documented by Miliani et al. ${ }^{18}$ testifies to a high degree of experimentation and innovation in the early days of the production.

Primary XRF analyses of the golden decorations (Figs 1 and 6) have revealed the presence of different techniques to obtain a gilded look: i) a true gilding with gold, ii) an application of gold associated with mercury as amalgam gilding or as vermilion-containing paint underlayer ${ }^{32}$, and ii) an alloy of copper and zinc. The use of pure gold on all gilded decors was clearly observed on the brown dish (SB 8405, Fig. 1) and black saucer (SB 2244-9). Gilding associated with mercury was applied on the surface of the brown teapot (SB 2244-10) and brown saucer (SB 7115-2). For the latter object the Raman spectrum collected on the 'gilded' area shows also peaks characteristics of reddish-yellow $\mathrm{PbO}$, indicating a glaze saturated with $\mathrm{PbO}$ or a $\mathrm{PbO}$ painting layer, or an oily medium of application that contained a $\mathrm{PbO}$ drier. An alloy of copper and zinc was encountered on the coffee pot (A 1995.96) and tea caddy (PC 18).

In their study on the glaze and decors of Böttger stoneware, Miliani et al. ${ }^{18}$ mentioned that the gilding decoration most widely used was made of brass for general purposes and gold for finer decorations. The gilded decoration on the lobed dish with German L \& C heraldic symbol, SB 8405, is almost pure gold (the minor Cu content arising from the contribution of the Cu-rich glaze (Fig. 5)). It is applied with particular skill as is apparent in the disposition of 
the scrolling tendrils along the undulating border and in the entwined monogram topped by a ducal coronet. This contrasts with the more generic kinds of gilded patterns such as the leaves on the cup and saucer (SB 2244_9).

The objects SB2244-9 cup, SB 2244-10 teapot, SB 7115-2 saucer and SB 8405 dish were chosen for further XRF analysis with the aim of confirming the composition of gold decors analyzed previously. The ability to visualize the analyzed area with the Niton instrument helped to identify different spots, with good or poor adhesion of the gilded decoration (Fig. 7). The analyses showed that small amounts of mercury was partly present on the gilding of all objects. Visual examinations of the gilding decor in different places under tangential lighting show that the mercury-rich area generally correspond to areas of discontinuous gilding. Large amounts of sulphur were detected in all objects analyzed. This is both consistent with the use of amalgam to stick a gold leaf on an area where the adhesion of gold was poor after the firing and/or with the use of a ferrous sulfate procedure. However the spot size and related spatial resolution of the instruments used do not allow differentiation of mercury-based compounds promoting the gold adhesion with incompletely gilded area or vermillion lines applied to demarcate the area to be gilded. ${ }^{16}$

\section{Conclusion}

The synergistic use of XRF and Raman instruments to investigate the glazes and decoration of Böttger stoneware offers a powerful combination for the complete characterization of these technologically advanced and aesthetically refined precious objects. While XRF analysis gives semi-quantitative information about the elements present in the body and gilded decoration, its use is limited to the characterization of black and brown glazes, as the interaction volume of the XRF beam is invariably larger than the glaze layer alone except for a gilded surface (a $0.2 \mu \mathrm{m}$ gold film is sufficient to stop the X-Ray beam). On the other hand, 
Raman analysis, which is a surface analysis, with penetration of the order of approximately 550 microns in the conditions used, allows classification of the glaze composition type and provides access to information about the firing parameters (reducing atmosphere, low or high firing temperature) through the detection of specific phases and the calculation of the polymerization index.

Of the 21 objects studied, the analysis revealed two groups of dark glazes fired at higher or lower temperatures, with the black glazes showing higher $\mathrm{Mn}$ and $\mathrm{Cu}$ content, as measured with XRF. The colored décor of many objects was confirmed to be applied by cold painting over the brown or black lead-rich enamel and included some materials, such as gypsum, calcium phosphate and arsenate whites that have not been documented for Böttger stoneware previously and would warrant further investigation on other collections of these objects. The evidence of different types of gilding with pure gold (physically or chemically bound to the substrate), gold associated with mercury (by restoration or complementing the original technique because the poor quality of the fired gilding) and brass gilding confirms the great variability of procedures and high degree of experimentation during the years in which Böttger invented and presided over the production of red stoneware, making it material for high artistic expression.

\section{Acknowledgments}

Horiba-Jobin Yvon is gratefully acknowledged for making the SuperHead available in the US. The authors thank Mr Eric Moinet Chief Curator, Head of Conservation Department, Mrs Virginie Desrante and Stéphanie Brouillet, Curators (Département du Patrimoine et des Collections de la Cité de la Céramique, Sèvres, France) for help and useful discussions. This study was partly supported in the USA by the Andrew W. Mellon Foundation through the Art Institute of Chicago-Northwestern University Collaboration in Conservation Science and in 
France by the LabEx MiChem a French state fund managed by the ANR within the Investissements d'Avenir programme under reference ANR-11-IDEX-0004-02. 


\section{References}

1. X. Steinbruck, Report to the Meissen factory, 1717, as cited in D. Syndram \&U. Weinhold “Böttger stoneware: Johann Friedrich Böttger and treasury art”, Berlin: Deutscher Kunstverlag. p. 123 (2009)

2. E. A. Barber, “So-called “Red Porcelain”, or Boccaro Ware of the Chinese, and its Imitations”, Bull Pennsylvania Museum, 9 [34] 17-23 (1911).

3. W. Funk, Die Rohstoffe der Feinkeramik: Ihre Aufbereitung und Verarbeitung zu Massen und Glassuren, Springer, Berlin, Heidelberg, (1933).

4. B. Ullrich, "Vergleichende Untersuchungen an Historischen Deutschen und Chinesischen Steinzeugen des Frühen 18. Jahrhunderts” Silikat Technik, 41 328-330 (1990).

5. M. D. Gutter, Through the Looking Glass: Viewing Böttger and Other Red Stoneware; San Francisco CA, Gutter Press, (1998).

6. C. H. Nelson, “Böttger stoneware: What science can tell us”, pp. 34-43 in The International Fine Art and Antique Dealers Show Ceramic Catalogue, (1998).

7. C. P. Swann and C. H. Nelson, "Böttger stoneware from North America and Europe; Are They Authentic”, Nuclear Instruments and Methods in Physics Research Section B: Beam Interactions with Materials and Atoms, 694 161-163 (2000).

8. Ph. Colomban, G. Sagon and X. Faurel, "Differentiation of Antique Ceramics from the Raman Spectra of Their Coloured Glazes and Paintings”, J Raman Spectrosc., 32 [5] 351-360 (2001).

9. Ph. Colomban and V. Milande, “On Site Analysis of the earliest known Meissen Porcelain and Stoneware”, J. Raman Spectrosc., 37 [5] 606-613 (2006). 
10. A. Bezur and F. Casadio, "Du Paquier Porcelain_Artistic Expression and Technological Mastery: a Scientific Evaluation of the Materials”; pp. 1163-1214 in Fired by Passion: Vienna Baroque Porcelain of Claudius Innocentius du Paquier. Volume 3, Chapter 14, Du Paquier porcelain: collectors, scientific evaluation, catalogue, and references; Edited by M. Chilton and C. Lehner-Jobst, Stuttgart, Melinda and Paul Sullivan Foundation for the Decorative Arts, Hartford, and Arnoldsche Art Publishers, (2009).

11. B. Ullrich, P. Lang and K. Friedmar, “Thüringer und Meissener Porzellan des Späten 18. und Frühen 19. Jahrhunderts-ein Werkstoffhistorischer Vergleich”, Keramische Zeitschrift, 62 [3] 185-190 (2010).

12. P. T. Bishop and P. A. Sutton in Gold:Science and Applications, C. Corti and R. Holliday, Eds, CRC Press -Taylor and Francis Group, Chapter 15 Decorative Gold Materials, 2010 pp335-337.

13. K. Domoney, J. Shortland and S. Kuhn, “Characterization of $18^{\text {th }}$ century Meissen Porcelain using SEM-EDS”, Archaeometry, 54 [3] 454-474 (2012).

14. F. Casadio, A. Bezur, K. Domoney, K. Eremin, L. Lee, J. Mass, A. Shortland and N. Zumbulyadis, “X-ray Fluorescence Applied to Overglaze Enamel Decoration on $18^{\text {th }}$ and $19^{\text {th }}$ century Porcelain from Central Europe”, Stud Conserv., 57 [S1] 61-72 (2012).

15. A. Bezur, F. Casadio, “The Analysis of Porcelain using Handheld and Portable X-ray Fluorescence Spectrometer”, pp. 249-311, in Studies in Archaeological Sciences: Handheld XRF for Art and Archaeology; Edited by A. Shugar and J. Mass, Leuven, Leuven University Press, (2013).

16. A. Loesch, “Sächsisch Schwartz lacquirtes Porcelain: das Schwarz Glasierte Böttgersteinzeug im Bestand der Dresdner Porzellansammlung”; Staatliche Kunstsammlungen Dresden and Sandstein Verlag Dresden, (2013). 
17. G. Simsek, F. Casadio, Ph. Colomban, L. Bellot-Gurlet, K. T. Faber, G. Zelleke, V. Milande and E. Moinet, “On-Site Identification of Early Böttger Red Stoneware Made at Meissen Using Portable XRF: 1, Body Analysis”, J. Am. Ceram. Soc. 97 [9] 2745-2754 (2014).

18. C. Miliani, B. Doherty, A. Daveri, A. Loesch, H. Ulbricht, B. G. Brunetti, A.Sgamellotti, "In situ non-invasive investigation on the painting techniques of early Meissen Stoneware“, Spectrochimica Acta Part A 73 587-592 (2009).

19. N.Q. Liem, Ph. Colomban, G. Sagon, H.X. Tinh and T.B. Hoanh, "Microstructure, Composition and Processing of the $15^{\text {th }}$ century Vietnamese Porcelains and Celadons”, J. Cultural Heritage 4 [3] 187-197 (2003).

20. Ph. Colomban, Th. Calligaro, Cl. Vibert-Guigue, N. Q. Liem and H.G.M. Edwards, "Accrochage des dorures sur les céramiques et tesselles anciennes", Revue d'Archéométrie-ARCHEOSCIENCES 29 7-20. (2006).

21. P. Ricciardi, Ph. Colomban, A. Tournié and V. Milande, “Non-destructive on-site identification of ancient glasses: genuine artefacts, embellished pieces or forgeries ?“, $J$. Raman Spectrosc. 40 604-617 (2009).

22. W. Goder, W. Schulle, O. Wagenbreth and H. Walter, La découverte de la porcelaine européenne en Saxe Böttger, J. F. Pygmalion-Gérard Watelet Press, (1984).

23. Ph. Colomban, "Polymerization Degree and Raman Identification of Ancient Glasses used for Jewelery, Ceramics Enamels and Mosaics“, J. Non-Crystalline Solids 323 [1-3] 180187 (2003).

24. Ph. Colomban, "On-site Raman identification and dating of ancient glasses: procedures and tools“, J. Cultural Heritage 9 [Suppl.] e55-e60, (2008). 
25. Ph. Colomban, A. Tournié, L. Bellot--Gurlet, “Raman Identification of glassy silicates used in ceramic, glass and jewelry: a tentative differentiation guide“, J. Raman Spectrosc. 37 [8] 841-852 (2006).

26. Ph. Colomban and O. Paulsen, "Raman Determination of the Structure and Composition of Glazes“, J. Am. Ceram. Soc. 88 [2] 390-395 (2005)

27. Ph. Colomban and A. Slodczyk, "Raman intensity: an important tool to study the structure and phase transitions of amorphous/crystalline materials“, Optical Materials 31 [12] 1759-1763 (2009).

28. Ph. Colomban, I. Robert, C. Roche, G. Sagon and V. Milande, "Identification des porcelains “tendres” du $18^{\text {ème }}$ siècle par spectroscopie Raman: Saint-Cloud, Chantilly, Mennecy et Vincennes/Sèvres“, Revue d’Archéométrie 28 153-167 (2004).

29. Ph. Colomban, A. Tournié, M.-C. Caggani and C. Paris, "Pigments and enamelling/gilding technology of Mamluk mosque lamps and bottle“, J. Raman Spectrosc. 43 [12] 19751984 (2012).

30. Ph. Colomban, "The on-site/remote Raman analysis with portable instruments - A review of drawbacks and success in Cultural Heritage studies and other associated fields“, $J$. Raman Spectrosc. 43 [11] 1529-1535 (2012).

31. F. Froment, A. Tournié and Ph. Colomban, "Raman identification of natural red to yellow pigments: ochre and iron-containing ores“, J. Raman Spectrosc. 39 [5] 560-568 (2008).

32. B. Kirmizi, Ph. Colomban and M. Blanc, “On-site Analysis of Limoges enamels from $16^{\text {th }}$ to $19^{\text {th }}$ century“, J. Raman Spectrosc. 41 [10] 1240-1247 (2010).

33. Ph. Colomban, V. Milande and H. Lucas, “On-site Raman Analysis of Medici Porcelain.” J. Raman Spectrosc., 35 [1] 68-72 (2004). 
34 G. Simsek, Ph. Colomban, S. Wong, B. Zhao, A. Rougeulle and N.Q. Liem, "Toward a fast non-destructive identification of pottery: the sourcing of $14^{\text {th }}-16^{\text {th }}$ century Vietnamese and Chinese ceramic shards“, J. Cultural Heritage (2014), DOI: $\underline{10.1016 / j . c u l h e r .2014 .03 .003 ~}$

35 J. Barrelet, "Perrot et le verre français", Cahiers de la céramique du verre et des arts du feu: Sèvres, 36, 254-270 (1964). 

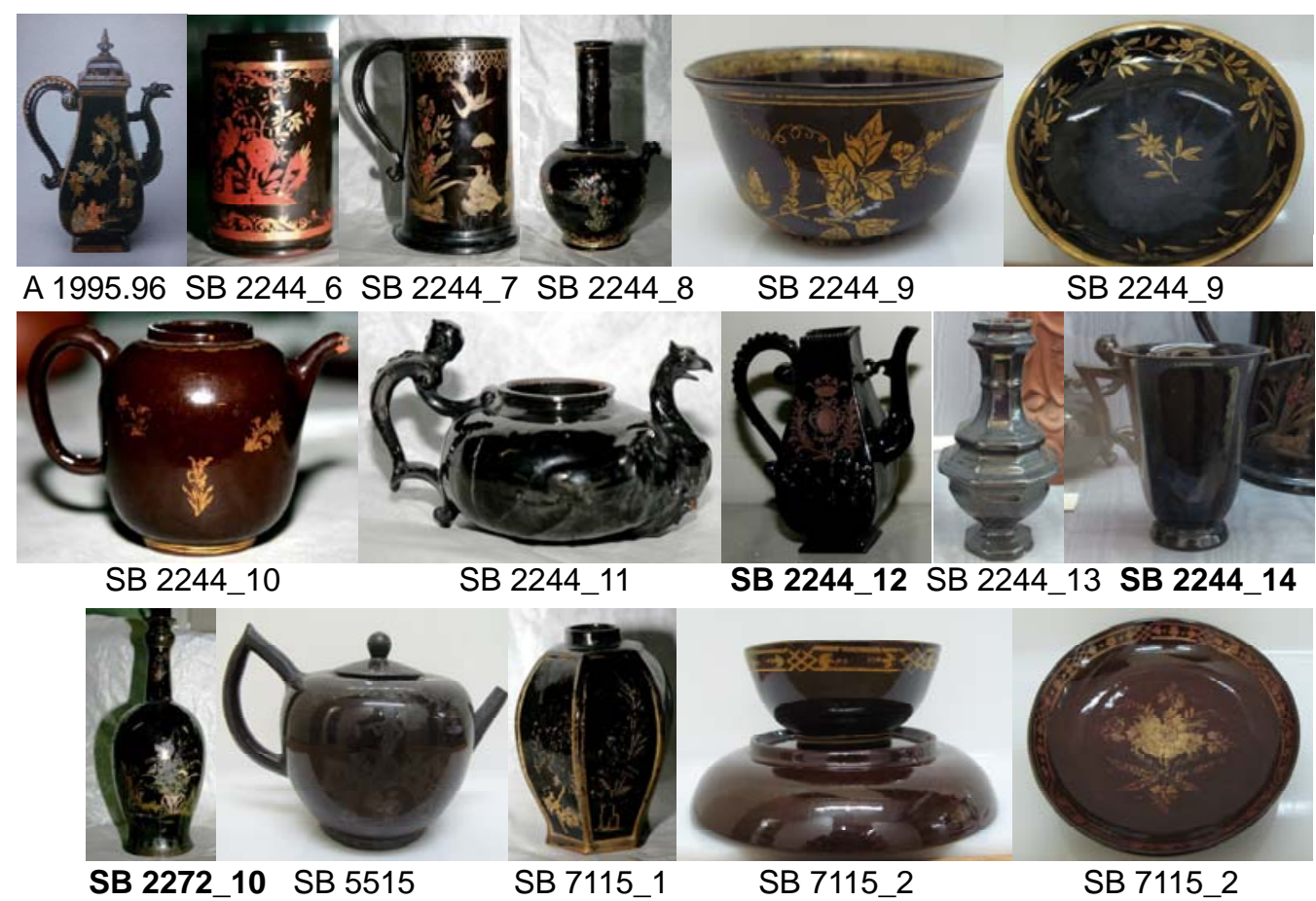

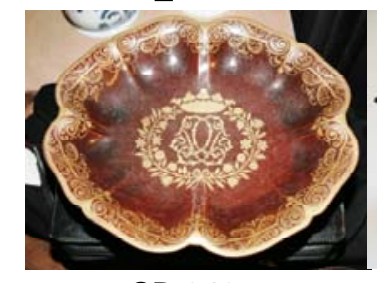

SB 8405

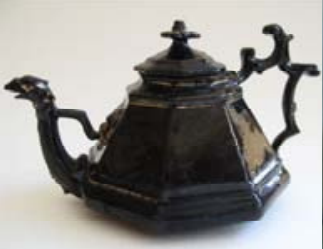

PC 6

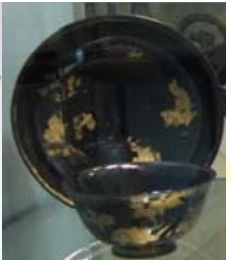

PC 8

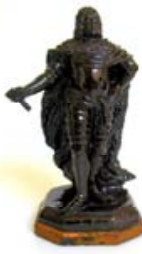

PC 10

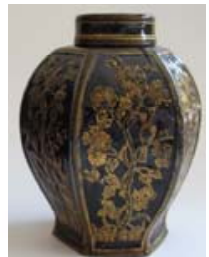

PC 18

Figure 1: Representative views of glazed Böttger red stoneware (SB*, Sèvres Collection, $A^{*}$, Art Institute of Chicago Collection and PC, Private Collection; details in Table S1, Supplementary Materials). Codes in bold represent the artefacts whose body composition has been previously studied with $\mathrm{XRF}^{17}$.

Suggestion for images:

SB 7115_2 Now shows cup on inverted saucer. Would you consider cropping the saucer out so that the cup is better featured? 


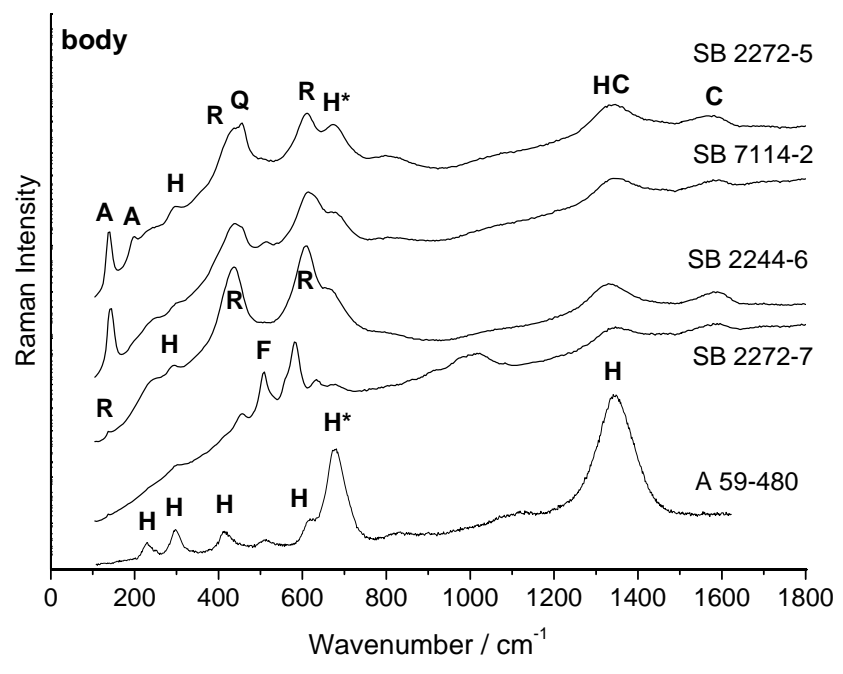

Figure 2: Representative as recorded Raman spectra showing the phases found in the bodies of unglazed red Böttger red stoneware as described in ref.17. The peaks characteristic of the different phases are labeled: $\mathrm{H}$, hematite; $\mathrm{H}^{*}$, hematite and magnetite mixture; Q, quartz; R, rutile; A, anatase; F, feldspar; C, carbon. 
a)

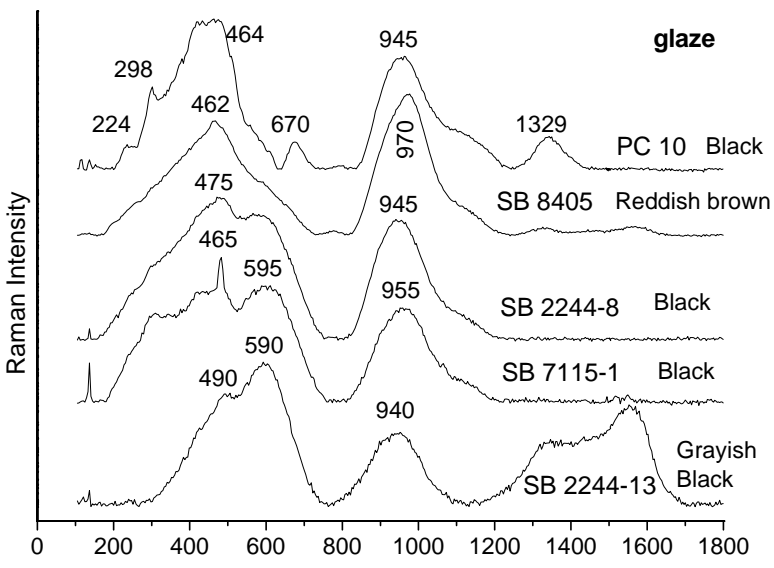

b)
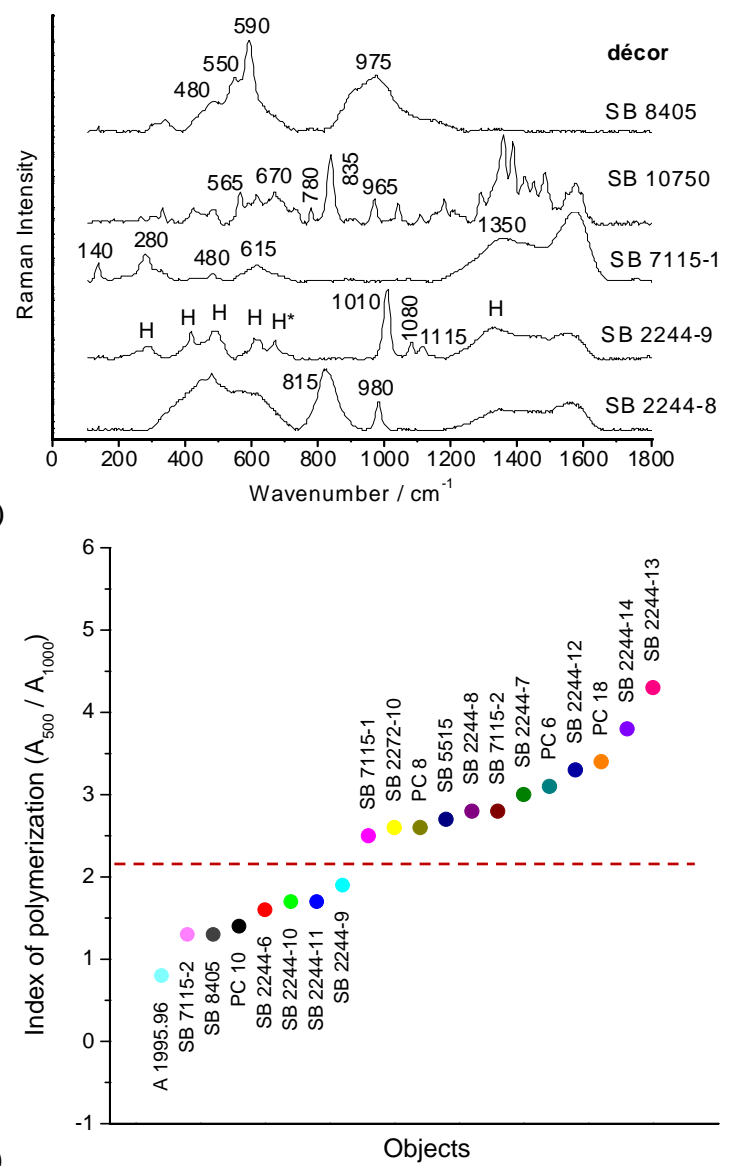

c)

Figure 3: Representative baseline-subtracted Raman spectra recorded on the glaze (a) and décor (b) of the objects examined for this study; the Index of polymerization is given in (c). 

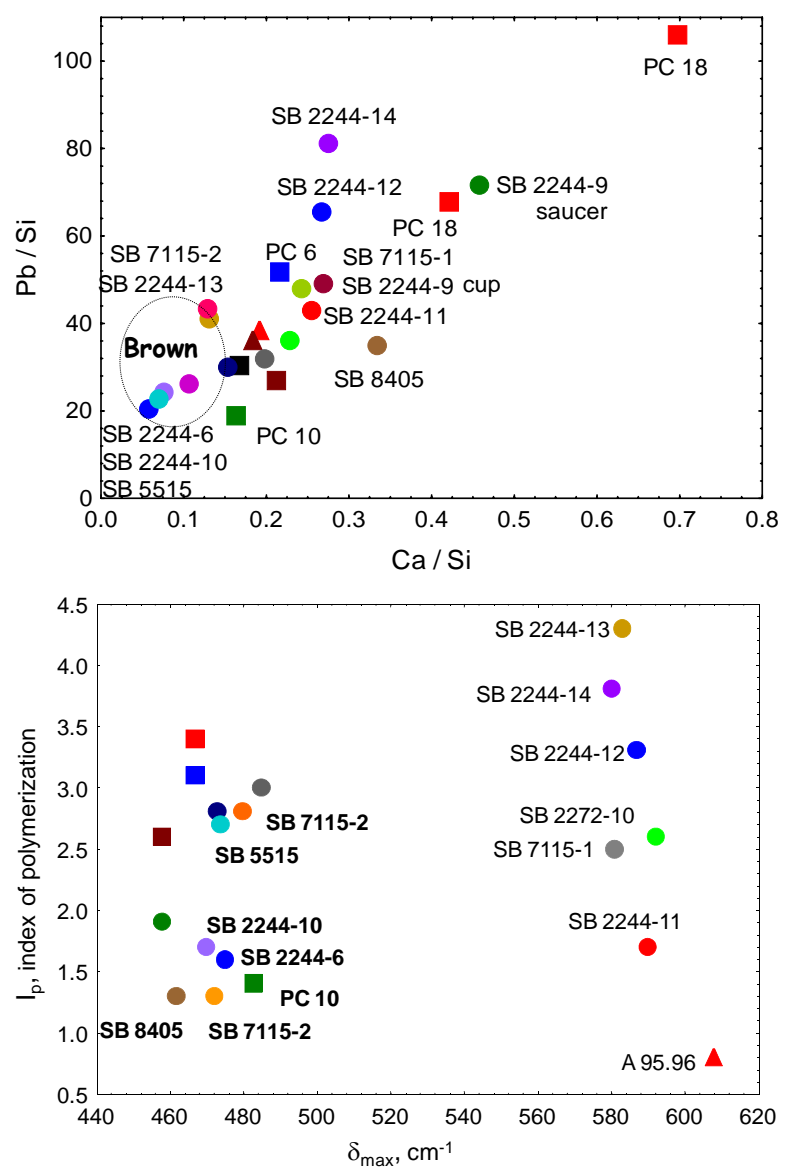

Figure 4: Scatterplot of $\mathrm{Pb} / \mathrm{Si}$ versus $\mathrm{Ca} / \mathrm{Si} \mathrm{XRF}$ mean net area counts (33 kV excitation energy) showing the variation of the composition measured on the glaze. Data obtained from the Art Institute of Chicago, USA, (solid triangle), Cité de Céramique, Sèvres, France (solid circle), private collection (solid square, see Table 1 for labels). b) Calculated index of polymerization $\left(\mathrm{I}_{\mathrm{p}}\right)$ vs position of the maxima of the Raman Si-O bending band $\left(\delta_{\max }, \mathrm{cm}^{-1}\right)$ for brown and black glaze. 


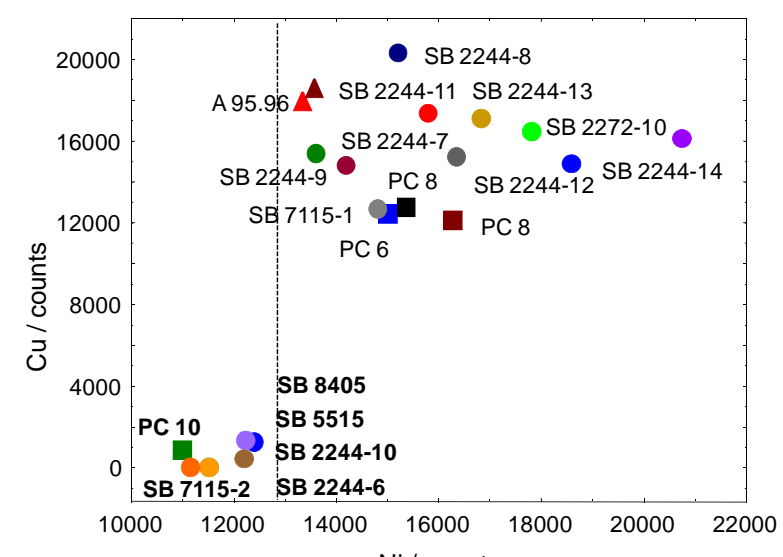

a)

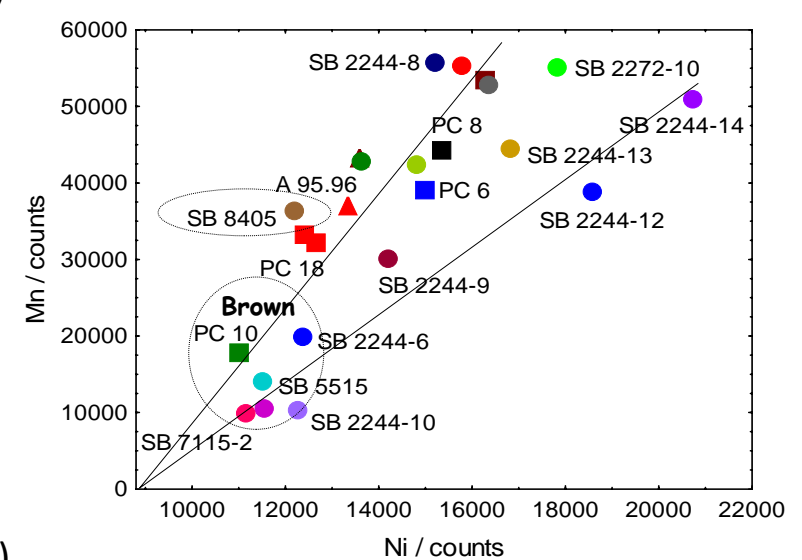

b)

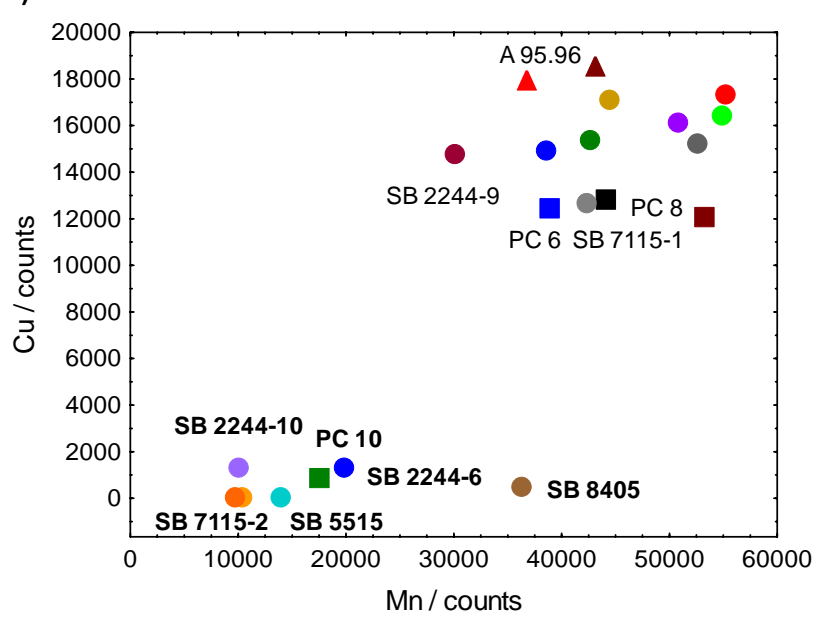

c)

Figure 5: Scatterplot of Cu vs Ni (a), Mn vs. Ni (b) and Cu vs. Mn XRF number of counts for the glazed objects. 

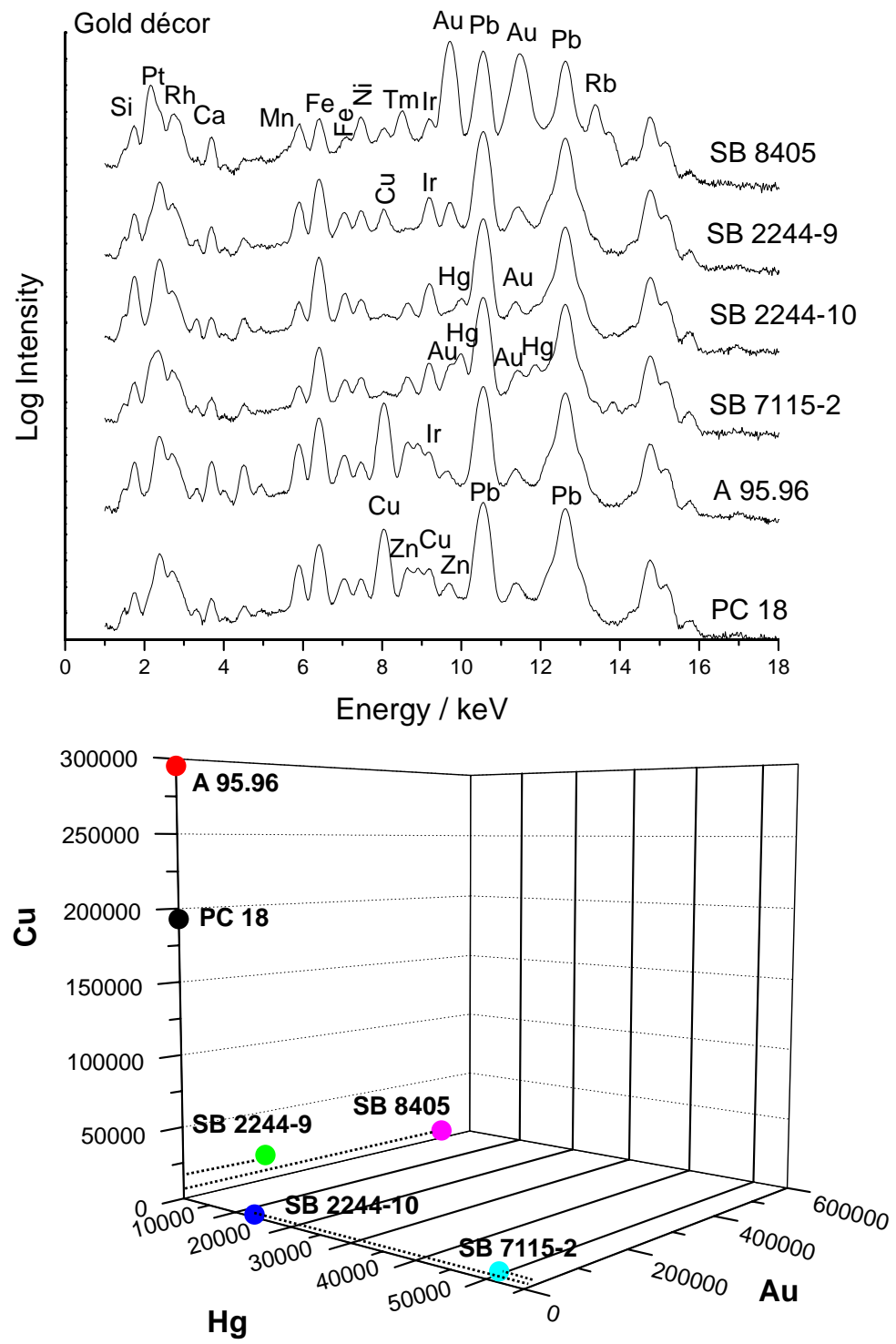

Figure 6: Representative XRF spectra of gold décors of different composition $(\mathrm{Au}, \mathrm{Au}+\mathrm{Hg}$ and $\mathrm{Cu}+\mathrm{Zn}$ ) and scatterplot of $\mathrm{Hg}$, $\mathrm{Au}$ and $\mathrm{Cu}$ XRF count number recorded on the golden color. 

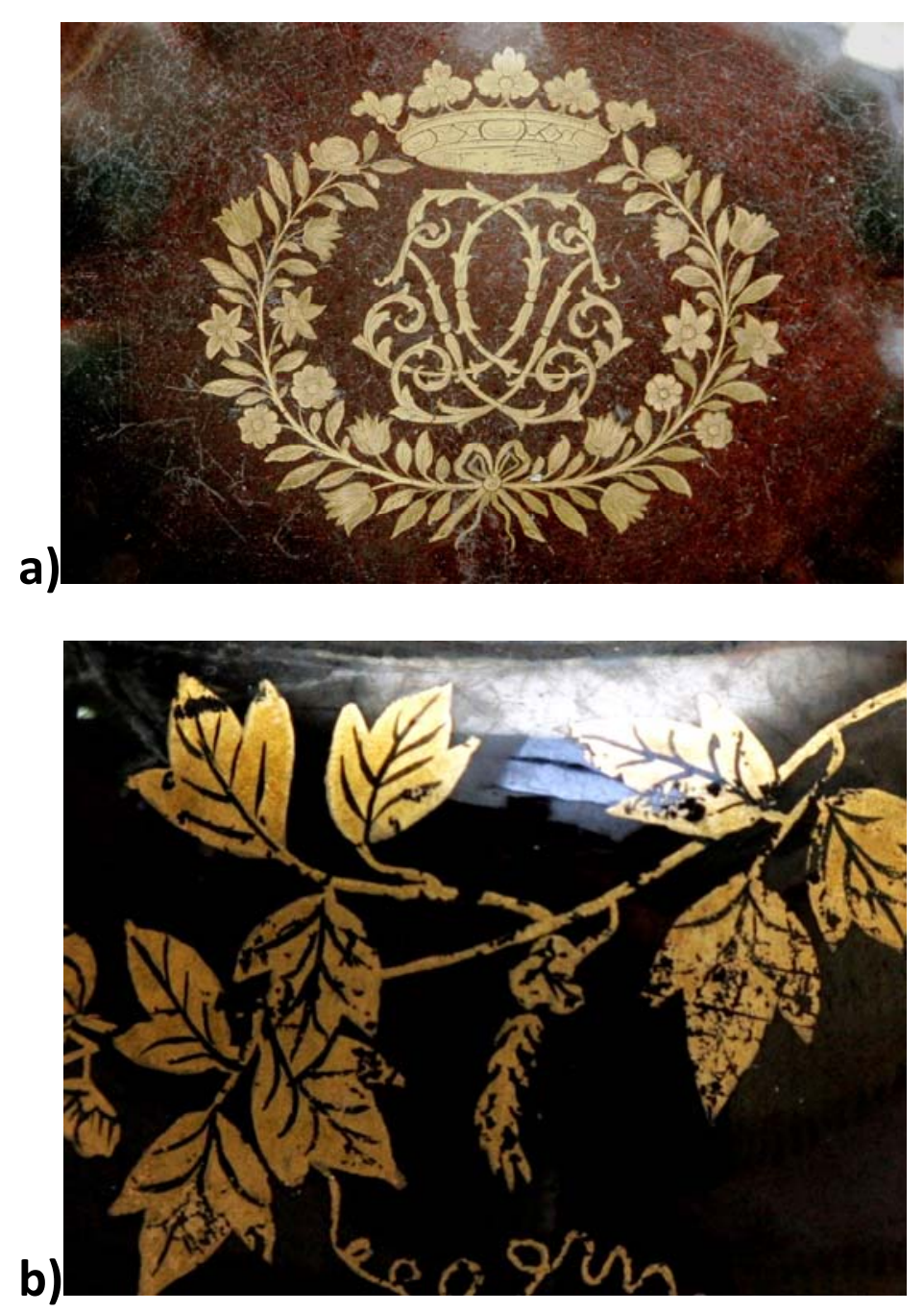

Figure 7 : Detail of the gilded area for SB 8405 dish (a) and SB 2244-9 bowl. 
Table 1. Description of glazed Böttger red stoneware including measured CIE Lab factors, L: lightness, a (red) and b (yellow): color-opponent dimensions.

\begin{tabular}{|c|c|c|c|c|c|c|}
\hline Code & Object & $a^{*}$ & $\mathrm{~b}^{*}$ & $\mathrm{~L}^{*}$ & $\begin{array}{l}\text { Glaze } \\
\text { color }\end{array}$ & Surface \\
\hline A 1995.96 & Coffeepot & & & & Black & Unfired colors and gilded \\
\hline SB $2244 \_6$ & Tankard & & & & Brown & Gilded \\
\hline SB 2244_7 & Tankard & 2.34 & 0.13 & 4.18 & Black & $\begin{array}{l}\text { Unfired colors and gilded } \\
\text { CHECK }\end{array}$ \\
\hline SB 2244_8 & Sake bottle & 1.21 & -0.16 & 6.27 & Black & Unfired colors and gilded \\
\hline SB 2244_9 & Saucer & 2.29 & -0.93 & 19.14 & Black & Gilded \\
\hline SB 2244_9 & Cup & 9.60 & 5.11 & 13.32 & Black & Gilded \\
\hline SB 2244_10 & Teapot & 9.29 & 10.34 & 14.76 & Brown & Gilded \\
\hline SB 2244_11 & Teapot & 0.53 & -0.81 & 9.01 & Black & No décor \\
\hline SB 2244_12 & Coffeepot & 1.92 & -1.32 & 7.88 & Black & Partially glazed \\
\hline SB 2244_13 & Vase & & & & Black & No décor \\
\hline SB 2244_14 & Cup & 0.64 & -1.37 & 5.41 & Black & No décor \\
\hline SB 2272_10 & Vase & 2.83 & 0.09 & 4.16 & Black & Unfired colors and gilded \\
\hline SB 5515 & Teapot & 4.92 & 5.93 & 14.25 & Brown & Décor \\
\hline SB 7115_1 & Tea caddy & 1.26 & -0.61 & 6.20 & Black & Gilded \\
\hline SB 7115_2 & Saucer & 12.93 & 15.27 & 13.18 & Brown & Gilded \\
\hline SB 7115_2 & Cup & 8.28 & 6.37 & 14.21 & Brown & Gilded \\
\hline SB 8405 & Plate & 13.28 & 12.83 & 19.41 & Brown & Gilded \\
\hline PC 6 & Teapot & & & & Black & Gilded \\
\hline PC 8 & Cup \& Saucer & & & & Black & Gilded \\
\hline PC 10 & Figure & & & & Black & Gilded base \\
\hline PC 18 & Tea caddy & & & & Black & Gilded \\
\hline
\end{tabular}




\section{On-site identification of early Meissen Böttger red stoneware made}

at Meissen using portable XRF/Raman instruments: 2, glaze and gilding analyses

G. Simsek ${ }^{1,2,3}$, Ph. Colomban ${ }^{4 *}$, F. Casadio ${ }^{3}$, L. Bellot-Gurlet ${ }^{4}$, K.T. Faber ${ }^{1}$, G. Zelleke ${ }^{3}$, V. Milande ${ }^{5}$, and L. Tilliard ${ }^{5}$

${ }^{1}$ Department of Materials Science and Engineering, Northwestern University, Evanston, IL, USA

${ }^{2}$ Labex MiChem, Ladir, UPMC, 4 Place Jussieu, c49, 75252 Paris Cedex 05, France

${ }^{3}$ Art Institute of Chicago, Chicago, IL, USA

${ }^{4}$ Sorbonne Universités, MONARIS, umr 8233 CNRS, UPMC Univ. Paris 06, 4 Place Jussieu, c49, 75252 Paris Cedex 05, France

${ }^{5}$ Cité de la Céramique - Sèvres \& Limoges, Place de la Manufacture, 92310 Sèvres, France

* corresponding author: Ph. Colomban philippe.colomban@upmc.fr

Supplemental Figures 


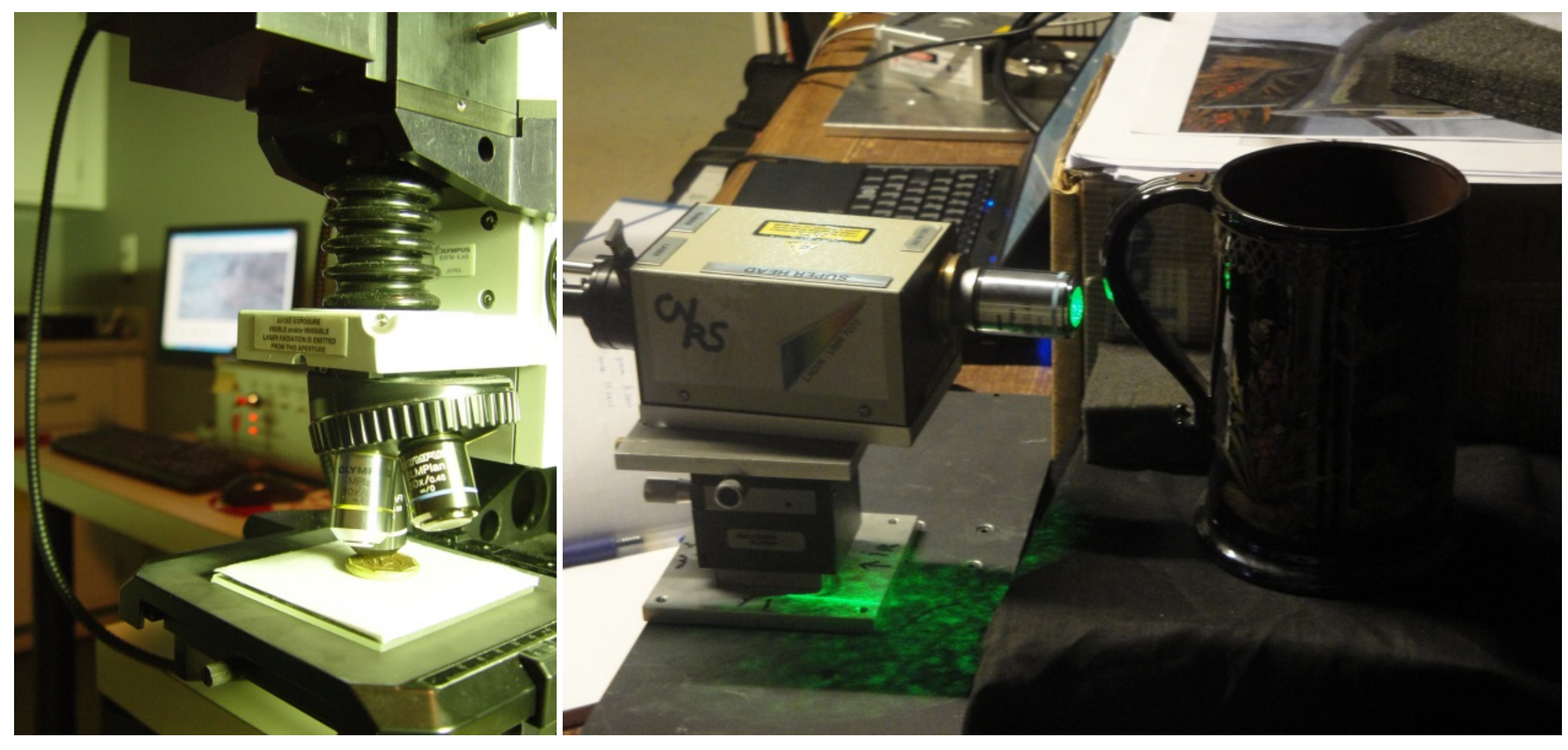

Figure S1: A laboratory (left) and portable (right) Raman set up. The distance between object and portable instrument is $15 \mathrm{~mm}$. A black textile is put on both the remote head and artifact before increasing the laser power at the required level to screen off unwanted ambient light. 

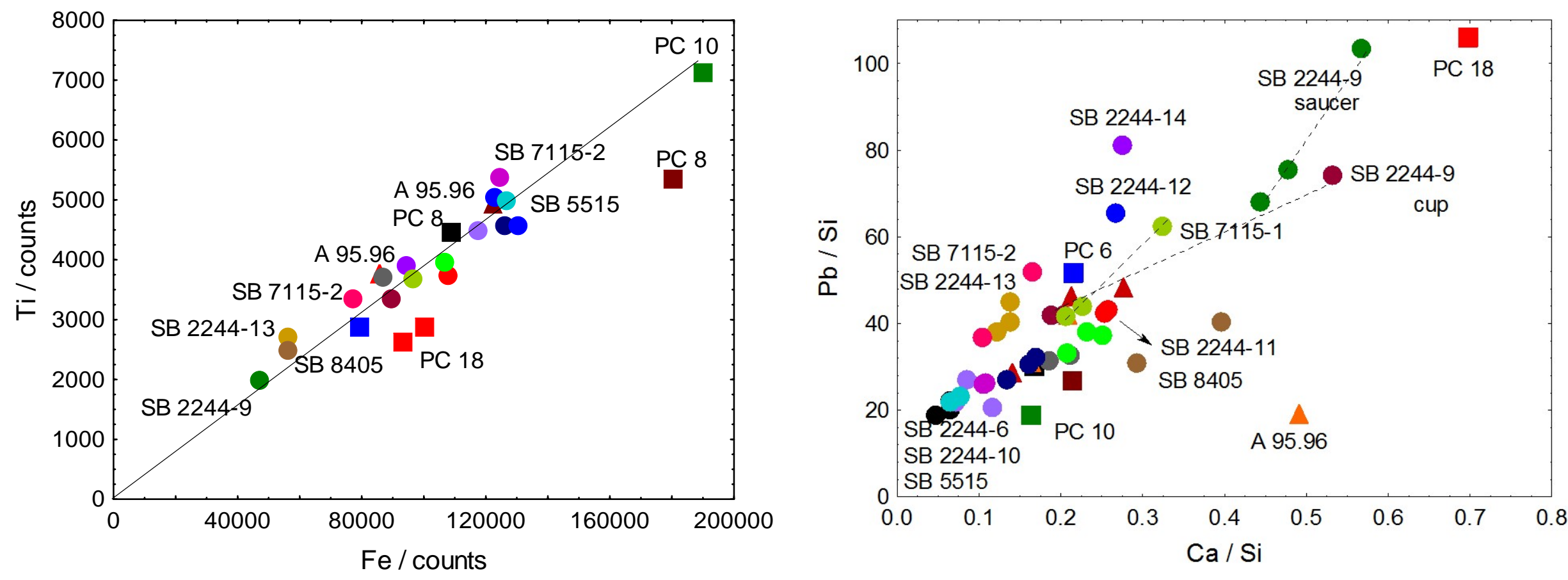

Figure S2: Scatterplot of Ti vs Fe XRF net area counts and Pb vs. Ca (normalized by Si). 


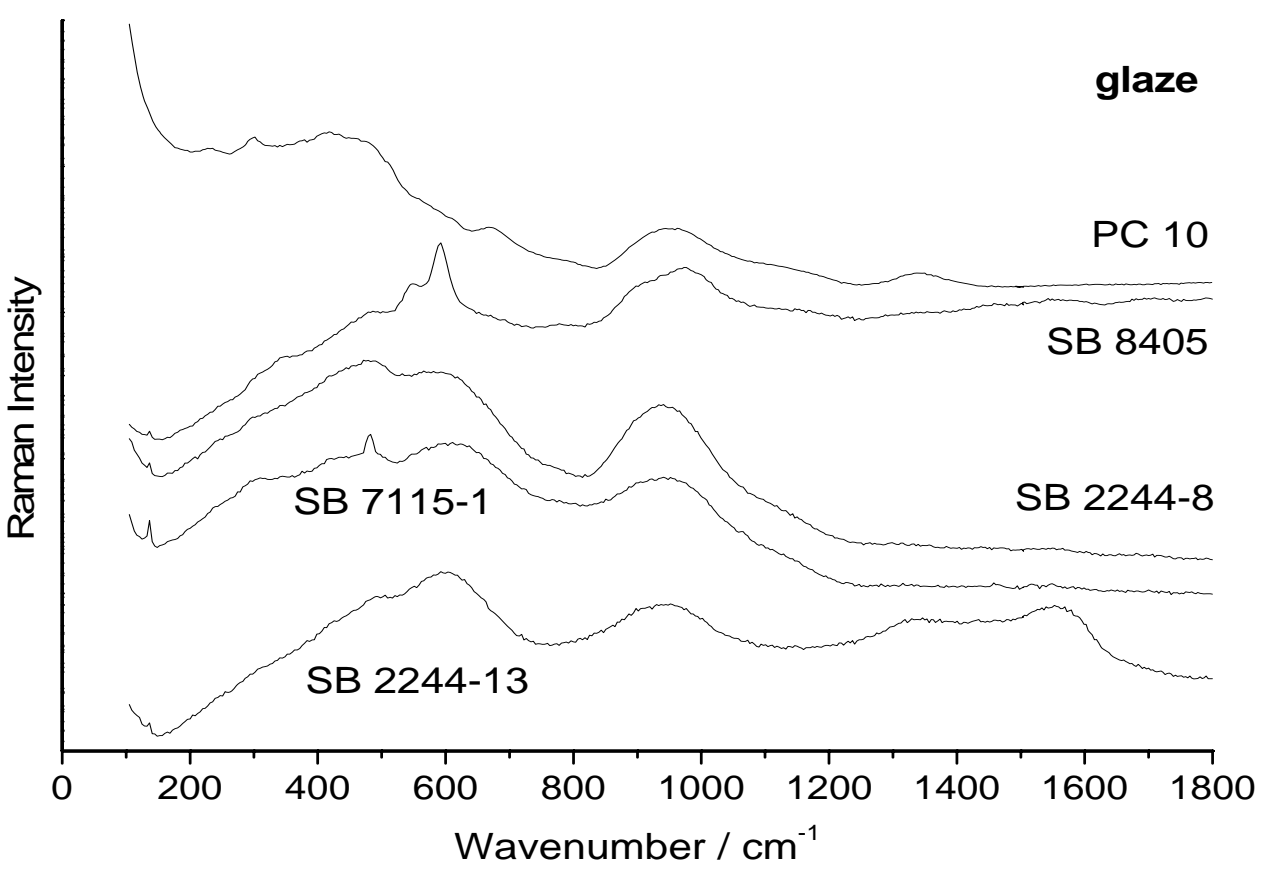

a)

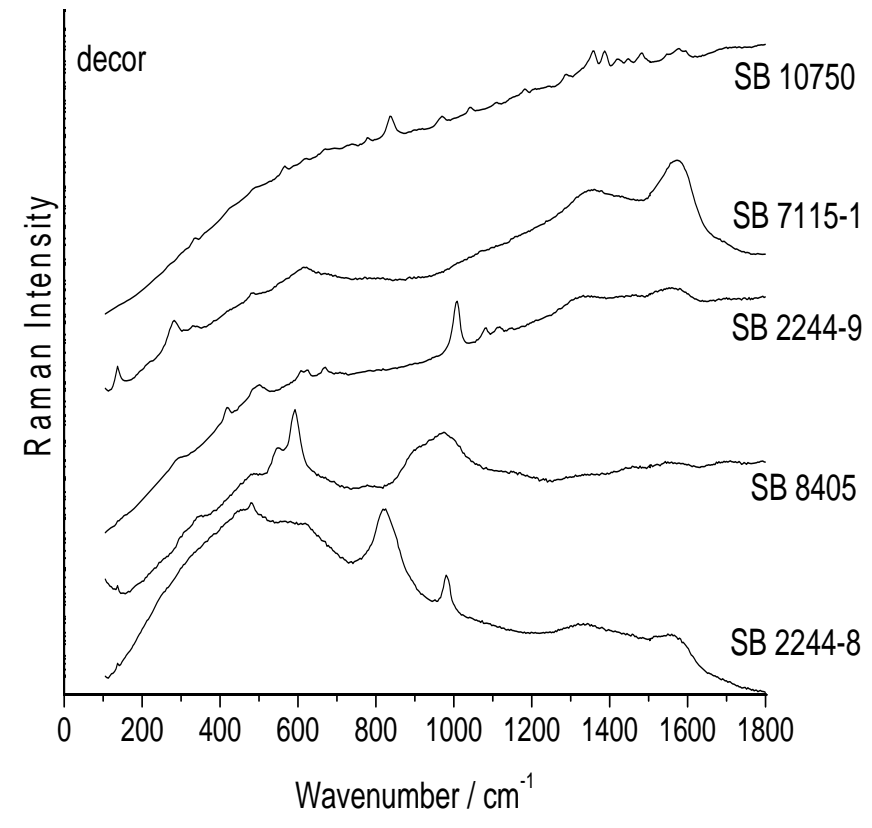

b)

Figure S3: Representative as recorded Raman spectra on glaze (a) and overglaze decoration (b). 


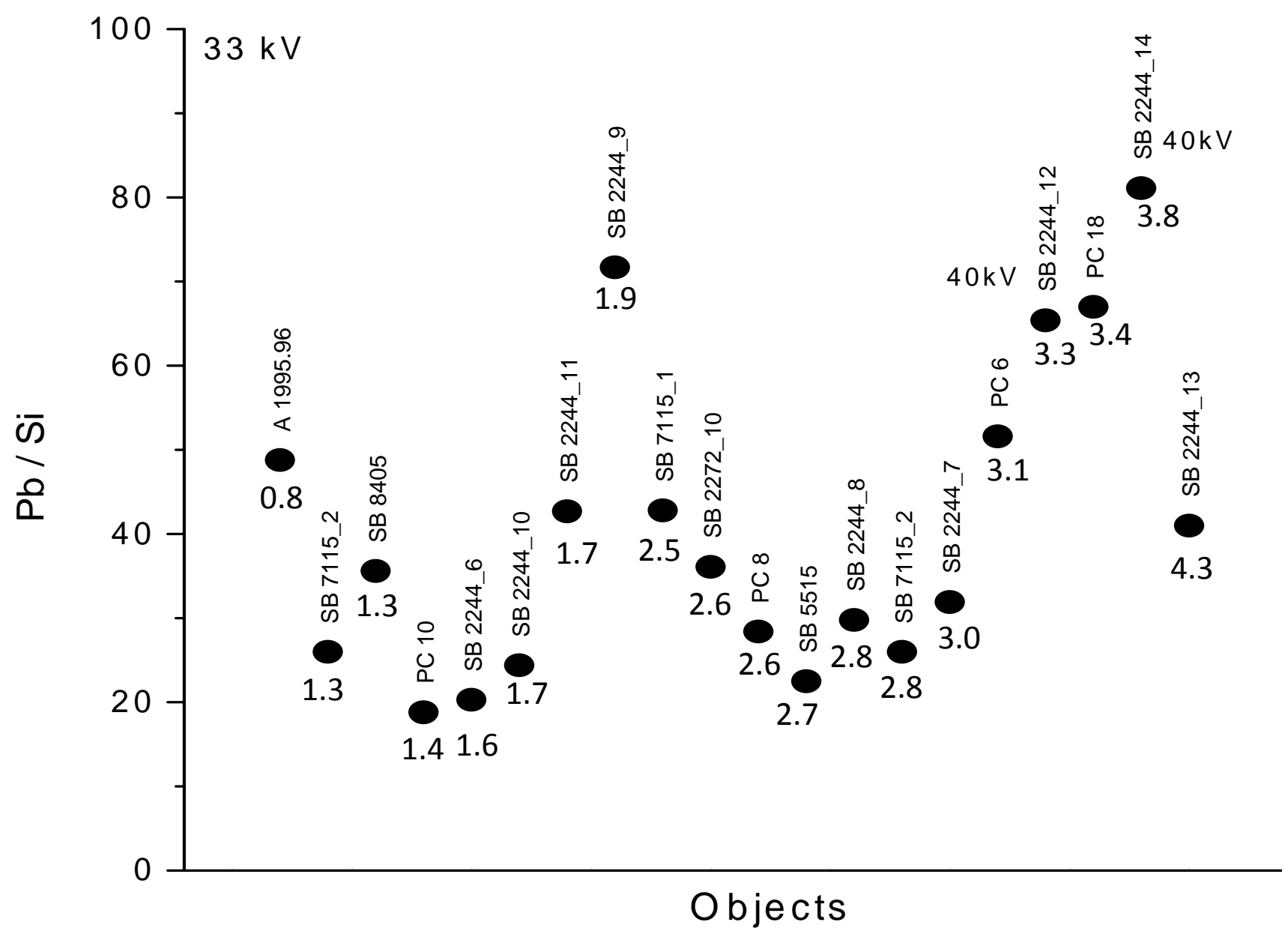

Figure S4. XRF Pb net area counts normalized by Si. The objects are listed according to their increasing Ip value (see below the labels) (see Fig. 3c). 


\begin{tabular}{|c|c|c|c|c|c|c|c|c|c|}
\hline $\begin{array}{c}\text { Inventory } \\
\text { number }\end{array}$ & $\begin{array}{c}\text { Object's } \\
\text { identifier } \\
\text { (this } \\
\text { article) }\end{array}$ & Object & $\begin{array}{l}\text { Artisan (if } \\
\text { known) }\end{array}$ & $\begin{array}{l}\text { Production } \\
\text { Year } \\
\text { (estimated) }\end{array}$ & $\begin{array}{l}\text { Production } \\
\text { place }\end{array}$ & $\begin{array}{l}\text { Dimensions } \\
\text { (cm) }\end{array}$ & $\begin{array}{c}\text { Acquisition } \\
\text { date }\end{array}$ & $\begin{array}{c}\text { Motive of } \\
\text { acquisition }\end{array}$ & Picture \\
\hline 1995.96 & $\begin{array}{c}A \\
1995.96\end{array}$ & $\begin{array}{c}\text { Coffee } \\
\text { pot }\end{array}$ & & 1715 & $\begin{array}{c}\text { Meissen } \\
\text { Factory }\end{array}$ & $20.5 \times 13.5 \times 9.1$ & 1995 & $\begin{array}{l}\text { Restricted gift of } \\
\text { Mrs. Marilynn } \\
\text { Alsdorf in } \\
\text { memory of her } \\
\text { husband }\end{array}$ & \\
\hline $\begin{array}{l}\text { MNC } \\
2244-6\end{array}$ & $\begin{array}{c}\text { SB } \\
2244-6\end{array}$ & Tankard & Böttger & 1715 & $\begin{array}{l}\text { Meissen } \\
\text { Factory }\end{array}$ & 14x13x9.1 & 1836 & $\begin{array}{l}\text { Purchased in } \\
\text { Dresden } \\
\text { by Brongniart }\end{array}$ & \\
\hline $\begin{array}{l}\text { MNC } \\
2244-7\end{array}$ & $\begin{array}{c}\text { SB } \\
2244-7\end{array}$ & Tankard & & $1713-1720$ & $\begin{array}{l}\text { Meissen } \\
\text { Factory }\end{array}$ & $16.7 x 11.7 \times 5.5$ & 1836 & $\begin{array}{l}\text { Purchased in } \\
\text { Dresden } \\
\text { by Brongniart }\end{array}$ & \\
\hline $\begin{array}{l}\text { MNC } \\
2244-8\end{array}$ & $\begin{array}{c}\text { SB } \\
2244-8\end{array}$ & $\begin{array}{l}\text { Sake } \\
\text { Bottle }\end{array}$ & & $\begin{array}{l}\text { 18th } \\
\text { century }\end{array}$ & $\begin{array}{l}\text { Meissen } \\
\text { Factory }\end{array}$ & $17 x 11$ & 1836 & $\begin{array}{l}\text { Purchased in } \\
\text { Dresden } \\
\text { by Brongniart }\end{array}$ & \\
\hline $\begin{array}{l}\text { MNC } \\
2244-9\end{array}$ & $\begin{array}{c}\text { SB } \\
2244-9\end{array}$ & $\begin{array}{l}\text { Cup \& } \\
\text { Saucer }\end{array}$ & Böttger & 1710 & $\begin{array}{l}\text { Meissen } \\
\text { Factory }\end{array}$ & $2.8 \times 13.4$ & 1836 & $\begin{array}{l}\text { Purchased in } \\
\text { Dresden } \\
\text { by Brongniart }\end{array}$ & \\
\hline
\end{tabular}




\section{$9.3 \times 4.5$}

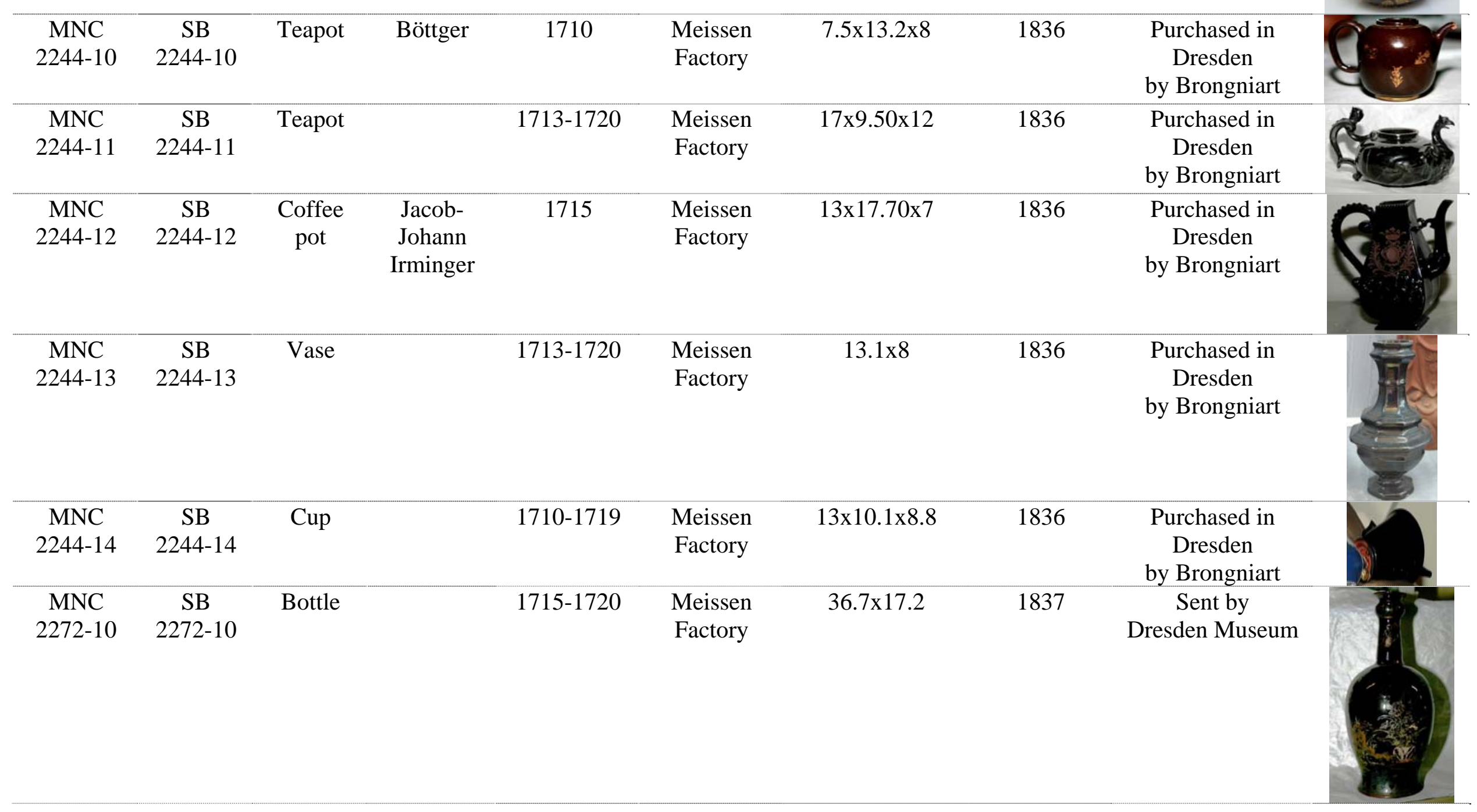




\begin{tabular}{|c|c|c|c|c|c|c|c|c|}
\hline $\begin{array}{l}\text { MNC } \\
5515\end{array}$ & SB 5515 & Teapot & Böttger & 1710 & $\begin{array}{l}\text { Meissen } \\
\text { Factory }\end{array}$ & $10.3 \times 16.5 \times 10.2$ & 1860 & $\begin{array}{c}\text { Gift of } \\
\text { Charles de Férol }\end{array}$ \\
\hline $\begin{array}{l}\text { MNC } \\
7115-1\end{array}$ & $\begin{array}{c}\text { SB } \\
7115-1\end{array}$ & $\begin{array}{l}\text { Tea } \\
\text { caddy }\end{array}$ & & $1713-1720$ & $\begin{array}{l}\text { Meissen } \\
\text { Factory }\end{array}$ & $12 \times 11$ & 1875 & $\begin{array}{c}\text { Gift of } \\
\text { Dresden Museum }\end{array}$ \\
\hline $\begin{array}{l}\text { MNC } \\
7115-2\end{array}$ & $\begin{array}{c}\mathrm{SB} \\
7115-2\end{array}$ & $\begin{array}{l}\text { Cup \& } \\
\text { Saucer }\end{array}$ & Böttger & 1710 & $\begin{array}{l}\text { Meissen } \\
\text { Factory }\end{array}$ & $\begin{array}{c}\text { Saucer: } \\
2.5 \times 12.3 \\
\text { Cup: } \\
3.4 \times 7.4\end{array}$ & 1875 & $\begin{array}{c}\text { Gift of } \\
\text { Dresden Museum }\end{array}$ \\
\hline $\begin{array}{l}\text { MNC } \\
8405\end{array}$ & SB 8405 & Dish & Factory & 1710 & Meissen & $\begin{array}{l}\text { Plate } \\
32,8 \times 28,5 \times 5,8 \\
\mathrm{~cm}\end{array}$ & 1885 & $\begin{array}{c}\text { Bequest of } \\
\text { Baron Charles } \\
\text { Davillier }\end{array}$ \\
\hline
\end{tabular}

Table S1: A selection of the studied objects that are part of publicly accessible collections 


\begin{tabular}{|c|c|c|c|c|}
\hline Code & $v, \mathrm{~cm}^{-1}$ & $\delta, \mathrm{cm}^{-1}$ & $I_{p}$ & Estimated firing $\mathrm{T}\left({ }^{\circ} \mathrm{C}\right)$ \\
\hline A 1995.96 & 970 & 608 & 0.8 & $<900$ \\
\hline SB 2244_6 & 955 & 475 & 1.6 & $<1000$ \\
\hline SB 2244_7 & 961 & 485 & 3 & $<1200$ \\
\hline SB 2244_8 & 955 & 473 & 2.8 & $<1200$ \\
\hline SB 2244_9 & 943 & 458 & 1.9 & $<1000$ \\
\hline SB 2244_9 & & & & \\
\hline $\begin{array}{c}\text { SB } \\
2244 \_10\end{array}$ & 952 & 470 & 1.7 & $<1000$ \\
\hline $\begin{array}{c}\text { SB } \\
2244 \_11\end{array}$ & 958 & $470 / 590$ & 1.7 & $<1000$ \\
\hline $\begin{array}{c}\text { SB } \\
2244 \_12\end{array}$ & 951 & $475 / 587$ & 3.3 & $<1400$ \\
\hline $\begin{array}{c}\text { SB } \\
2244 \_13\end{array}$ & 953 & 583 & 4.3 & $<1400$ \\
\hline $\begin{array}{c}\text { SB } \\
2244 \_14\end{array}$ & 966 & 580 & 3.8 & $<1400$ \\
\hline $\begin{array}{c}\text { SB- } \\
2272 \_10\end{array}$ & 964 & 592 & 2.6 & $<1200$ \\
\hline SB 5515 & 940 & 474 & 2.7 & $<1200$ \\
\hline SB 7115_1 & 964 & 581 & 2.5 & $<1200$ \\
\hline SB 7115_2 & 952 & 472 & 1.3 & $<1000$ \\
\hline SB 7115_2 & 934 & 480 & 2.8 & $<1200$ \\
\hline SB 8405 & 969 & 462 & 1.3 & $<1000$ \\
\hline PC 6 & 947 & 467 & 3.1 & $<1400$ \\
\hline PC 8 & 944 & 458 & 2.6 & $<1200$ \\
\hline PC 10 & 945 & 483 & 1.4 & $<1000$ \\
\hline PC 18 & 940 & 467 & 3.4 & $<1400$ \\
\hline
\end{tabular}

Table S2. Raman parameters of the glaze structure, representing $v \Sigma_{1}-\mathrm{O}$, stretching peak; $\delta$ Si-O bending peak; $\mathrm{I}_{\mathrm{p}}$, polymerization index and estimated firing temperature. ${ }^{23-26}$ 